\title{
Application of GI-TPS Model to Skills Critical Thinking and Self Efficacy
}

\author{
Rusmansyah $^{1}$, Asranudin ${ }^{2}$ \\ ${ }^{1}$ Prodi Pendidikan Kimia, Universitas Lambung Mangkurat, Banjarmasin, Indonesia \\ ${ }^{1}$ Email: rusmansyah_kimia@unlam.ac.id \\ ${ }^{2}$ Prodi Pendidikan Kimia, Universitas Lambung Mangkurat, Banjarmasin, Indonesia \\ 2Email: asrndn13@gmail.com
}

(Received: September-2017; Reviewed: October-2017; Accepted: November-2017; Published: December-2017)

(C)2017 -EST Graduate Program Universitas Negeri Makassar. This is an article with open access under license CC BY-NC-4.0 (https://creativecommons.org/licenses/by-nc/4.0/ ).

\begin{abstract}
This research aims to know the: (1) the difference in critical thinking ability of students (2) difference in the results of learning (cognitive, affective, psychomotor) (3) self efficacy of students (4) student response towards the learning model GI-TPS (Guided InquiryThink Pair Share) on the hydrolysis of salt. This research use the pretest-posttest design nonequivalent control group design. A sample of 50 research students, namely class XI IPA 2 and XI IPA 3. Samples taken with purposive sampling technique. Engineering data collection using the test the critical thinking ability, cognitive learning results, observations, and the now. Analytical techniques descriptive analyses using data and analysis inferensial (test, test the normality of its homogeneity, and t-test). The results of this study suggest that (1) there is a difference significant critical thinking abilities (2) there is a difference in learning outcomes (cognitive, affective, psychomotor) a significant (3) students who have self efficacy. (4) the students gave positive response towards the learning model GI-TPS material on the hydrolysis of salt.
\end{abstract}

Keywords: Guided Inquiry, Think Pair Share, critical thinking abilities, self efficacy.

\section{INTRODUCTION}

Data from the 2012 PISA Survey (Wibowo, 2016) shows that the average selfefficacy score of students in Indonesia is 375, whereas the average international self efficacy score is 494 . This survey places Indonesia only at the 63rd rank of 64 participating countries. These results can show that the self efficacy of students in Indonesia is still far below the average of students from other countries. The lack of self efficacy of students is due to the learning process done by the teacher is still less to improve students' self efficacy ability so that many students are less confident with their ability in solving and organizing various chemical problems (Izzati, 2015).
Chemical learning during this tends to use lecture method and more centered on the teacher (teacher centered learning). Learning activities like this will make students quickly bored, passive and only get a material explanation submitted by the teacher without involving the students themselves in finding the concept on the chemistry lesson lessons, especially salt hydrolysis material, so that students can not measure the critical thinking ability that is owned by himself and lack of understanding of concepts in chemistry subject matter. Such learning can also be one of the factors of low self-efficacy of students and low critical thinking skills.

One of the learning that can help students to develop critical thinking ability and 
student learning outcomes is guided inquiry learning. Guided inquiry emphasizes student involvement in observing, investigating events, problems, phenomena specified in the curriculum. Students have more freedom to participate, conduct investigations and take ownership of their learning (Oliebie and Kate, 2014). Although it has been mentioned that guided inquiry learning has some positive advantages, but based on the results of field observations found that in fact there are still students who are less active in learning. These less active students cause difficulties in mastering the salt hydrolysis concept and developing their critical thinking skills.

One of the lessons that has the potential to develop students' activeness to optimize conceptual mastery, problem solving skills and critical thinking skills is to use Think Pair Share (TPS) learning model. According to Sampsel (2013) the learning model (TPS) is a cooperative learning in the classroom to give students the opportunity to actively process and develop meaningful understanding.

This research is done by merging the two learning models to get better result. The integration of the two into a new learning model known as the GI-TPS learning model (guided inquiry - think pair share). With guided inquiry learning, students can construct knowledge through experiment, thinking and questioning process, and with think pair share students become more active and able to think independently and work together to solve problems.

The GI-TPS Model syntax is as follows:

1. Problem orientation: the teacher distributes the student worksheet and guides to understand and answer the problem given by the teacher in the LKS;

2. Define the problem: the student group formulates the problems that exist in the LKS given by the teacher;

3. Preparing a hypothesis: teachers guide students to think, pair, and share the hypothesis-related issues that exist in the LKS;

a. Students are asked to think themselves to do every question or problem that is in LKS (phase think);

b. Students in pairs equate perceptions and discuss alternative answers to LKS (pair phase);

c. Group of students in pairs in turns to work on and explain the settlement of the problems contained in the LKS.

4. Collecting data: groups of students collect data from experimental results in the LKS to prove the hypothesis.

5. Testing the hypothesis: group of students meguji hypothesis that has been prepared after obtaining the results of data collection and answer questions in the LKS.

6. Make conclusions: students make conclusions on the material that was studied with teacher guidance.

\section{METHOD}

Research uses quasi experiments (quasy experiment). The research design is pretestposttest control nonequivalent group design (Sugiyono, 2012). In this design involves 2 classes, 1 class as the experimental class and 1 class as the comparison class. Both the experimental and comparative classes were pretested prior to the learning and post-test at the end of the study. Pre-test to know the student's initial ability before applied treatment. After the learning process, given the final test (post-test). Post-test to know the achievement of learning outcomes after being given treatment in both classes.

The research population of SMA Negeri 1 Tamban students in the academic year $2016 / 2017$. The sample used is taking two classes of samples from 3 class XI IPA. The sample of this research is students of class XI IPA 3 and XI IPA 2 SMA Negeri 1 Tamban. Sampling technique used porposive sampling. Purposive sampling is a technique of determining the sample with certain considerations (Sugiyono, 2012).

Collecting techniques are test and non test technique. The test technique is used to know the critical thinking skill of students with essay-like problem while the students' cognitive learning result is done with the instrument of objective matter (multiple choice) whose answer must be grounded. Nontes technique in the form of observation sheet to know the result of affective and psychomotor learning of the students filled by the observers that exist during the research and there are self efficacy questionnaires of students filled by the students at the last meeting meeting, the last in the form of a questionnaire response students response to learning on each - the class under study. 


\section{RESULTS AND DISCUSSION}

\section{Result}

The result of research related to the level of achievement of critical thinking skills is as follows with the indicator; (1) Analyze the argument, (2) Identify assumptions, (3) Ask and answer questions, (4) Decide action, (5) Induce.

Graph 1. Achievement of each indicator of critical thinking skills

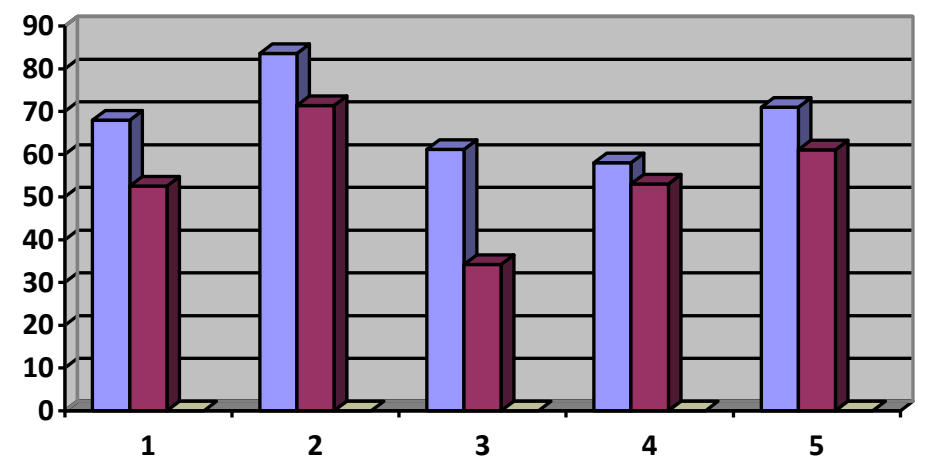

Table 1. Results of the post-test t-test of critical thinking skills

\begin{tabular}{lcccccl}
\hline \multicolumn{1}{c}{ Group } & $\mathrm{N}$ & $\mathrm{Db}$ & $\mathrm{SD}^{2}$ & $\mathrm{t}$ count & $\begin{array}{l}\mathrm{t} \text { tab } \\
(5 \%)\end{array}$ & \\
\cline { 1 - 4 } Experiment & 25 & 48 & 234,502 & & & $\begin{array}{l}\text { There is a } \\
\text { significant } \\
\text { difference }\end{array}$ \\
\hline Control & 25 & 48 & 218,898 & 3,120 & 2,021 & \\
\hline
\end{tabular}

Table 2. Price n-gain critical thinking skills

\begin{tabular}{ccl}
\hline Group & Average $N$-gain & Category \\
\hline Experiment & 0,60 & Medium \\
\hline Control & 0,45 & Medium \\
\hline
\end{tabular}

Furthermore, the percentage of student completeness, $t$ test and $n$-gain value in each class on the cognitive learning outcomes as follows:

Table 3. Percentage of mastery

\begin{tabular}{cccc}
\hline Value & Experiment & Control & Completeness \\
\hline$\geq 75$ & 22 & 19 & Completed \\
\hline$<75$ & 3 & 6 & Uncompleted \\
\hline
\end{tabular}

Table 3 shows that the experimental class is more accomplished than the comparison class. 
Table 4. Test of cognitive learning results

\begin{tabular}{|c|c|c|c|c|c|c|}
\hline Group & $\mathrm{N}$ & $\mathrm{Db}$ & $\mathrm{SD}^{2}$ & $t$ count & $\mathrm{t} \operatorname{tab}(5 \%)$ & \\
\hline Experiment & 25 & 48 & 50,063 & & & There is a \\
\hline Control & 25 & 48 & 75,000 & 2,059 & 2,021 & $\begin{array}{l}\text { significant } \\
\text { difference }\end{array}$ \\
\hline
\end{tabular}

Table 5. Price $n$-gain of cognitive learning outcomes

\begin{tabular}{ccc}
\hline Group & Average $N$-gain & Category \\
\hline Experiment & 0,73 & High \\
\hline Control & 0,68 & Medium \\
\hline
\end{tabular}

Result of self efficacy questionnaire value seen in Table 6 result of self efficacy questionnaire each indicator.

Table 6. Result of self efficacy questionnaire

\begin{tabular}{ccc}
\hline Group & Average & Criteria \\
\hline Experiment & 61,12 & Good \\
\hline Control & 57,56 & Enough \\
\hline
\end{tabular}

Comparison of affective learning outcomes can be seen in Table 7

Table 7. Affective learning outcomes

\begin{tabular}{lcc}
\hline Aspect & Experiment (\%) & Control (\%) \\
\hline Curiosity & 74 & 69,9 \\
\hline Responsible & 77 & 73,9 \\
\hline Cooperate & 74 & 69,9 \\
\hline Spread an opinion & 75 & 70,4 \\
\hline \multicolumn{1}{c}{ Average } & 75,2 & 70,8 \\
\hline Category & Good & Good \\
\hline
\end{tabular}

Comparison of psychomotor learning outcomes with details: (1) how to use dropper drops in taking solution (2) how to dispense solution into drop plate and dipping litmus (3) how to observe color change on litmus paper can be seen in Table 8 .

Table 8. Psychomotor learning results

\begin{tabular}{ccc}
\hline Performance Task Details & Experiment $(\%)$ & Control (\%) \\
\hline 1 & 70,40 & 68,00 \\
\hline 2 & 72,00 & 69,60 \\
\hline 3 & 75,20 & 74,40 \\
\hline Average & 72,53 & 70,67 \\
\hline Category & Skilled & Skilled \\
\hline
\end{tabular}

Table 9. Student response

\begin{tabular}{ccc}
\hline Group & $\begin{array}{c}\text { The average score of student } \\
\text { responses }\end{array}$ & Criteria \\
\hline Experiment & 41,08 & Good \\
Control & 38,80 & Good \\
\hline
\end{tabular}




\section{DISCUSSION}

The learning activities with the GI-TPS model from the first stage to the last stage applied in the experimental class reflect the processes that help students stimulate and improve students' critical thinking skills. Because students can find the concept independently. Learning with the GI-TPS model also makes the classroom atmosphere more enjoyable. This is because learning is the result of observation and influenced by the environment that students are actively involved in every stage of the learning process and also enthusiastic in solving problems.

Graph 1, Table 1, and Table 2 show there are different critical thinking skills between students with GI-TPS models and students with GI. So it can be stated that the GITPS model has a positive influence on critical thinking skills.

Table 1 shows the results of inferential analysis test using $t$ test that there is a difference in the experimental class using the GI-TPS model with the comparison class using the GI model, because by using the GI-TPS model which is an innovative learning so that the learning is more meaningful, fun and more effective.

Table 4 shows the achievement of experimental class cognitive learning outcomes using the GI-TPS model and the comparison class using the GI model. In Table 5 the n-gain price of the experimental class belongs to a high category.

Table 7 shows the affective learning outcomes observed during the ongoing learning show that on the experimental class aspect the average value is higher than the comparison class. This GI-TPS model also influences students' affective learning outcomes. Both the experimental class and the comparator class are good ones.

Table 8 shows the learning outcomes of psychographs that belong to a skilled category for both classes, both experimental and control classes. The experimental class has a higher value compared to the comparator class value, it is that the GI-TPS model is more influential than the GI model.

Table 9 shows that the experimental class gave a positive response to the application of the GI-TPS model compared to the comparator class applying the GI model. The GI-TPS model is a learning that not only finds the concept for critical thinking but trains the self-efficacy that students have with the GI-TPS step.

\section{CONCLUSIONS AND SUGGESTIONS}

Conclusions of the study are as follows: (1) There is a difference of critical thinking skill between students learning to use GI-TPS model with students using GI model on salt hydrolysis material. (2) There is a difference in learning outcomes between students learning to use the GI-TPS model with students learning to use the GI model on salt hydrolysis materials. (3) The self efficacy possessed by the students using the GI-TPS learning model is better than the students using the GI model. (4) a more positive response to learning using a GI-TPS learning model than with a GI learning model on salt hydrolysis material.

Suggestions for those who will apply the GI-TPS learning model in the learning activities, should manage time well because this model takes a longer time. And to examine the effectiveness of the GI-TPS model on critical thinking skills and self-efficacy of students in more depth, research is required by using 3 or 4 classes.

\section{REFERENCES}

Izzati, S. (2015). Implementation of the Type II Multiple Representative-Based Type I Learning Model In Improving Self Efficacy and Mastery of Acid Base Concepts. Skripsi. Bandar Lampung: FKIP Unila.

Olibie, E.I, Kate Oge Ezeoba. (2014). Ability and Location Differences in the Effects of Guided Inquiry on Nigerian Students' Achievement in Social Studies Curriculum. Journal of Education and Human Development. Volume 3, Nomor 4.

Sampsel, A. (2013). Finding the Effects of TinkPair-Share on Student Confdence and Participation. Journal. Bowling Green State University. 
Sugiyono. (2012). Metode Penelitian Pendidikan Pendekatan Kuantitatif, Kualitatif, dan $R$ \& $D$. Bandung : Alfabeta.

Sugiyono. (2012). Educational Research Methods Quantitative Approach, Qualitative, and R \& D. Bandung: Alfabeta.

Wibowo, T.H. (2016). Application of Guided Inquiry Model in Improving Self Efficacy and Mastery of Student Concept on Material of Electrolyte and Non Electrolyte Solution. Skripsi. Lampung : FKIP UNILA.

Wibowo, T.H. (2016). Application of Guided Inquiry Model in Improving Self Efficacy and Mastery of Student Concept on Material of Electrolyte and Non Electrolyte Solution. Essay. Lampung: FKIP UNILA. 